\title{
EDITORIAL
}

\section{Scholarship of Teaching and Learning (SoTL): Transformative Professional Development for Teachers}

\author{
Jana Hunzicker, EdD \\ Associate Dean for the College of Education and Health Sciences and Associate \\ Professor in the Department of Teacher Education \\ Bradley University
}

February is lambing season in Central Illinois. I know this because my dad is a sheep farmer. On a cold Sunday afternoon several weeks ago, while visiting Dad at our family farm, I walked with him to the barn to feed two bottle lambs. Right away, he noticed a ewe going into labor. He watched her closely as she paced in a circle, the other ewes backing away. She stood, then kneeled, then bellowed. Soon, we could see the hooves of the lamb about to be born. After a time, it became clear that she was struggling, so Dad entered the pen and waited nearby. Twenty minutes later, the newborn lamb lay steaming on the straw. Skillfully, Dad grasped it by its hind legs and carried it to a smaller pen that he had readied with fresh straw, the mother following closely behind. Settled into their own cozy space, the newborn lamb was soon clean, dry, and standing, ready to nurse. Its twin was born within the hour.

As I observed my dad, I was reminded of how different his work is from my own. Like most of you, my work as a teacher involves reading and writing, inquiring and collaborating, and discussing and presenting. I was prepared for my work by earning academic degrees and professional endorsements in college and university settings. My dad has a high school diploma, but he didn't learn how to breed and deliver sheep in school. He honed his craft through experience, first by working alongside more experienced farmers, and later with a great deal of practice, trial-anderror, and support.

Learning to be good at raising sheep is a lot like learning to be an effective teacher. Granted, a teacher's focus is on students instead of sheep, a classroom instead of a barn, and scholarly practice instead of casual reading and conversation, but the underlying motivation to try and the ongoing drive to succeed are the same. Sheep farmers and teachers alike spend their careers - and sometimes their entire lives striving to improve their craft.

What inspires sheep farmers, teachers, and others to strive toward improvement in their life's work? Part of the answer lies in understanding how adults learn. Malcolm Knowles (1970) asserted that adult learning is distinguished by four assumptions:

1) Adult learning is self-directed.

2) Adults learn by building on their life experiences.

3) Adults are motivated to learn when learning is relevant to their lives.

4) Adults are motivated to learn when they can immediately apply their learning.

My dad started raising sheep in 1954 as part of a grade school 4-H project. By high school his sheep had won a few blue ribbons, and he was hooked. Dad became a 
carpenter by trade but maintained a flock of sheep as a second source of income, refining his practice with each year of experience. Everything he learned about sheep interested him because he was committed to his flock, and most of what he learned could be applied immediately because it addressed actual problems.

Although critiqued by some as too anecdotal (Merriam, 2001), the four assumptions of adult learning are supported by neuroscience (Hagen \& Park, 2016). Because adults' brains are equipped with well-developed neurological frameworks, or schemata, adults are better prepared than school-aged learners to make cognizant choices about what they need to learn. In addition, adults can more readily assimilate and accommodate new information because they have more prior knowledge and experiences to connect with. Moreover, because humans are created and conditioned to be successful in their adult roles and responsibilities, adults are more likely than school-aged learners to see the relevancies and applications of their learning, especially when it is self-directed.

Merriam (2001) defines self-directed learning as "learning that is widespread, that occurs as part of adults' everyday life, and that is systematic yet does not depend on an instructor or a classroom" (p. 8). Self-directed learning is an ongoing process that involves setting goals for the purpose of intentionally developing knowledge or skills in a particular area. Because adult learning is self-directed, it is naturally grounded in past experiences and usually occurs within authentic contexts (Rohlwing \& Spelman, 2014). Self-directed learning also incorporates personal reflection and dialogue with others as means of cognitive processing, which can lead to lasting changes in thinking and decision-making over time (Drago-Severson, 2009; Rohlwing \& Spelman, 2014). Jack Mezirow (1990) called such lasting changes transformative learning.

I am licensed and experienced as a middle school teacher and elementary school principal, but when I entered higher education halfway through my career, I quickly realized that I had much to learn about effective college teaching. After a few embarrassingly tiresome class periods, I began adapting activities I had used with

I experienced firsthand that professional development becomes meaningful when teachers decide for themselves what they want to learn; develop and implement their own learning plan; and frequently reflect, discuss, and apply their learning. eighth graders to enliven my collegelevel classes. I also started attending teaching workshops at my university, and as I collected new teaching strategies, I tried them in my classroom. In order to succeed as a college teacher, I built on my experiences, sought useful information, and applied what I was learning at the first opportunity. I reflected and readjusted after almost every class period, and slowly my teaching improved. In the process, I experienced firsthand that professional development becomes meaningful when teachers decide for themselves what they want to learn; develop and implement their own learning plan; and frequently reflect, discuss, and apply their learning.

Without a doubt, meaningful professional development is good, but Scholarship of Teaching and Learning (SoTL) (known as action research in PK-12 education) is what makes professional development transformative. Closely aligned with the four assumptions of adult learning, SoTL is self-directed, allows us to build on prior experiences, relates directly to our teaching lives, and can be applied to our 
teaching practice immediately. But SoTL is more than self-directed adult learning. It is a systematic process of inquiry, focused on concerns related to the instructional practices and outcomes about which the investigating teacher cares deeply. Because SoTL projects are customized to the teacher, classroom, and students who will benefit most from the investigation, SoTL work is personal. The reflection and dialogue that occur through SoTL are authentic, prompting teachers to take ownership of both the SoTL research process and subsequent findings.

McKinney (2007) defines SoTL as "the systematic reflection/study of teaching and learning made public" (p. 8). Unlike discipline-specific research, SoTL focuses first on reflection and second on reporting. As Fanghanel (2013) explains, "The aim of SoTL is not to publish but to uncover the complexity of academic practice through reflection and engagement with relevant partners (colleagues, students) and to draw lessons that are subjected to debate and contradictions" (p. 63). In this way, engaging in SoTL work equips us to inspire better teaching and learning in others. Whether we share our SoTL efforts through a scholarly manuscript, during a concurrent session, or with a colleague over coffee, we positively influence the teaching profession by delineating a research process, revealing our findings, and modeling scholarly teaching.

My early attempts to succeed as a college teacher quickly morphed into SoTL work. My first SoTL project, in collaboration with a colleague, involved observing each other's classes to collect data on student engagement in learning, which we used to make improvements to our teaching practice. Later, I used similar data to compare an outdated teaching methods course with its newly-designed replacement, chronicling the teaching challenges I experienced during the transition. My third SoTL project involved a student survey exploring the written and verbal reflection of pre-service teachers, which I used to analyze the effectiveness of my class activities and assignments. With each SoTL project, my teaching knowledge increased; I honed my research skills, and I built a record of scholarship by presenting and publishing my findings. Currently, I am working on a SoTL project with four colleagues in another discipline, investigating how factors such as classroom space, furniture, and room arrangement impact teaching and learning in the health professions. Now in my twelfth year of college teaching, SoTL has transformed my own and others' teaching practice from mundane to memorable.

Regardless of the type of work we do, when we are passionate about it, we work hard and keep going until we get it right. For my dad, it was learning how to raise healthy and profitable flocks of sheep. For teachers, it's figuring out how to be the best teachers we can be. If you're a teacher who longs for transformative professional development, I encourage you to give SoTL a try. Engaging in the Scholarship of Teaching and Learning: A Guide to the Process, and How to Develop a Project from Start to Finish by Cathy Bishop-Clark and Beth Dietz-Uhler is an excellent place to begin. Through SoTL, we can become better teachers and positively influence our students and our colleagues, not just for an hour or for a semester, but for an entire career. 


\section{References}

Bishop-Clark, C., \& Dietz-Uhler, B. McKinney, K. (2007). Enhancing learning (2012). Engaging in the scholarship of through the scholarship of teaching and teaching and learning: A guide to the learning: The challenges and joys of process, and how to develop a project from juggling. San Francisco, CA: Jossey-Bass. start to finish. Sterling, VA: Stylus.

Drago-Severson, E. (2009). Leading adult learning: Supporting adult development in our schools. Thousand Oaks, CA: Corwin.

Fanghanel, J. (2013). Going public with pedagogical inquiries: SoTL as a methodology for faculty professional development. Teaching $\mathcal{E}$ Learning Inquiry, 1(1), 59-70.

Hagen, M., \& Park, S. (2016). We knew it all along! Using cognitive science to explain how andragogy works. European Journal of Training \& Development, 40(3), 171-190.

Knowles, M. S. (1970), The modern practice of adult education: Andragogy vs pedagogy. Chicago, IL: Follett.

Mezirow, J. (1990). How critical reflection triggers transformative learning. In J. Mezirow and Associates (Eds.), Fostering critical reflection in adulthood: A guide to transformative and emancipatory learning (pp. 1-20). San Francisco, CA: Jossey-Bass.

Merriam, S. B. (2001). Andragogy and self-directed learning: Pillars of adult learning theory. New Directions for Adult E Continuing Education, 89, 3-13.

Rohlwing, R. L., \& Spelman, M. (2014). Characteristics of adult learning: Implications for the design and implementation of professional development programs. In L. E. Martin, S. Krager, D. J. Quatroche, \& K. L. Bauserman (Eds.) Handbook of professional development in education: Successful models and practices, preK-12. New York, NY: The Guilford Press.

Jana Hunzicker is associate dean for the College of Education and Health Sciences and associate professor in the Department of Teacher Education at Bradley University. She previously served as executive director for her university's Center for Teaching Excellence and Learning (CTEL). Author of numerous articles about her SoTL work and effective professional development for teachers, Dr. Hunzicker is editor of the recently-published book Teacher Leadership in Professional Development Schools (Emerald Publishing, 2018). Currently, she and two colleagues are serving as guest editors for a special issue of School-University Partnerships journal, themed "The Impact of Teacher Leadership on Student Learning in Professional Development Schools," which will feature teacher-led action research projects. 